\title{
N-3АМЕЩЕННЫЕ С-ФОСФОРИЛИРОВАННЫЕ ДИИМИДАТЫ В РЕАКЦИИ АМИНИРОВАНИЯ
}

\section{В.Е. Шишкин, Ю.В. Попов, О.В. Анищенко, М.А. Шевченко, И.Д. Кравченко}

Волгоградский государственный технический университет 400005, Россия, г. Волгоград, проспект им. В.И. Ленина, д. 28.

DOI: 10.19163/MedChemRussia2021-2021-423

E-mail: anishchenko@vstu.ru

Фосфорилированные соединения оказались перспективными в лечении злокачественных опухолей, некоторых видов параличей, бронхиальной астмы, глаукомы, миастении и ряда других заболеваний. А фосфорорганические амидины предложено применять для лечения остеоартрита и ревматоидного артрита [1].

При взаимодействии гидрохлоридов С-фосфорилированных диимидатов малоновой кислоты с ацилирующими агентами в мягких условиях селективно образуются N-замещенные диимидаты малоновой кислоты. $\mathrm{N}$-замещенные C-фосфорилированные диимидаты аминировали алифатическими аминами с получением фосфорсодержащих диамидинов.

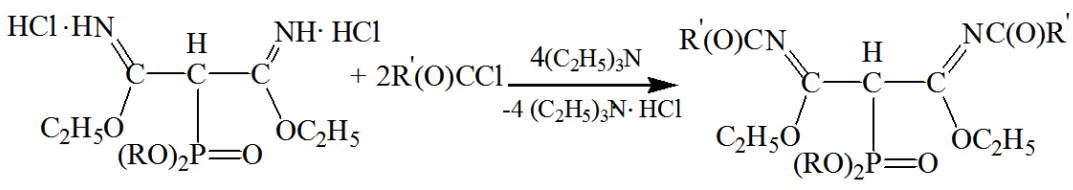

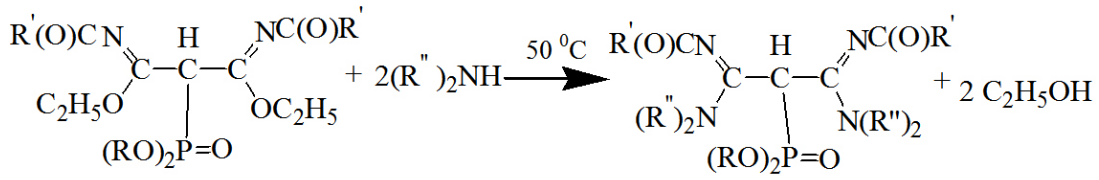

где $\mathrm{R}=\mathrm{CH}_{3}, \mathrm{C}_{2} \mathrm{H}_{5} ; \mathrm{R}^{\prime}=-\mathrm{CH}_{3},-\mathrm{C}_{6} \mathrm{H}_{5} ; \mathrm{R}^{\prime \prime}=-\mathrm{C}_{2} \mathrm{H}_{5},-\mathrm{C}_{3} \mathrm{H}_{7}$ где $\mathrm{R}=\mathrm{CH}_{3}, \mathrm{C}_{2} \mathrm{H}_{5} ; \mathrm{R}^{\prime}=-\mathrm{CH}_{3},-\mathrm{C}_{6} \mathrm{H}_{5} ; \mathrm{R}^{\prime \prime}=-\mathrm{C}_{2} \mathrm{H}_{5},-\mathrm{C}_{3} \mathrm{H}_{7}$.

Нами проведён вычислительный прогноз возможного наличия различных видов биологической активности. Для всех С-фосфорилированных имидатов и амидинов прогнозируется антипсориазная активность и ингибирующая активность в отношении таких ферментов, как диметилаллилтрансферазы, глицерил-эфир монооксигеназы, алкоголь-О-ацетилтрансферазы и других. Это позволяет рекомендовать полученные соединения для испытаний на биологических объектах.

\section{Литература}

[1] Пат. 6770669 US, MПК А 61 K 31/38. Amidine derevatives, preparation and use there of as medicines / Pierre-Etienne Chabrier, Jeremiah Harnett. - заявл. 15.11.2000, опубл. 3.08.2004. 